Gut, 1974, 15, 552-554

\title{
Why are small bowel tumours rare? An experimental model
}

\author{
K. C. CALMAN \\ From the Department of Surgery, Western Infirmary, Glasgow
}

SUMMARY It is a well known clinical observation that small bowel tumours are rarer than tumours of the stomach or colon. The fluidity and relative sterility of small bowel contents, and rapid transit time and of the relative sterility of the small bowel itself have been suggested as possible factors contributing to this relatively low incidence. A further mechanism, that of a local immune response against malignant cells, has also been suggested and this investigation is the subject of this paper. A transplantable tumour (Gardner lymphosarcoma) was injected either into the stomach or small bowel of CBA mice, and the incidence of subsequent tumour growth was studied when the immune status of the host mouse was altered. Normal mice, mice 'deprived' by thymectomy and irradiation (T-cell-deficient mice), and 'reconstituted mice' (prepared as the 'deprived' animals but given a thymus graft) were used. The results showed that in normal and reconstituted mice more tumours arise in the stomach than in the small bowel but that in deprived mice the incidence of tumours was the same in both sites. This could be taken to suggest that local immune responses can suppress the development of tumours of the small bowel.

It is a common clinical observation that tumours of the small bowel are rarer than tumours of the stomach and colon (Lowenfels, 1973). Many explanations have been offered: the fluid content of the small bowel may reduce exposure to any potential carcinogen: the rapid transit time of small bowel content is likely to decrease the contact time: the relative sterility of the small bowel compared with the large bowel may be important. A fourth hypothesis examined and reported in this communication is that there is an effective local immune response in the small intestine which militates against the development of tumours. The small bowel is an important lymphoid organ in its own right. It secretes large amounts of immunoglobulin as IgA (Samson, McClelland, and Shearman, 1973); it contains large numbers of lymphoid cells in the submucosa and in the epithelium, and there is now good evidence that lymphoid blast cells 'home' specifically to the small bowel (Moore and Hall, 1972). Peyer's patches and the mesenteric lymph nodes are a closely related mass of lymphoid cells (Ferguson and Parrott, 1972).

In recent years evidence has accumulated which suggests that the immune response does have some function in controlling the development of malignant tumours. This phenomenon, usually called immunosurveillance, gains support from observations in Received for publication 23 April 1974. patients in whom the immune response is depressed as in the immunodeficiency diseases (Gatti and Good, 1971). Patients on immunosuppressive therapy show a higher instance of tumours than normal (Penn and Starzl, 1972). Similarly there is an increase in the incidence of small bowel tumours in diseases with known immunological abnormalities such as Crohn's disease (Darke, Parks, Grogond, and Pollock, 1973) and coeliac disease (Barry and Read, 1973).

It may therefore be proposed that the immune system of the small intestine controls the development of tumours. To test this hypothesis an experimental model using a transplanted tumour innoculated into either the stomach or small intestine of mice of differing immunological states was used.

\section{Materials and Methods}

Male CBA mice 8-12 weeks of age were employed. They were caged in groups of five or six animals and given a standard mouse diet and water ad libitum. Three groups of animals were used of differing immunological status. At least 20 animals were used in each group. The first were normal CBA mice. The second group were mice, thymectomized, given a lethal dose of radiation $(800 \mathrm{r})$ then injected with $5 \times 10^{6}$ syngeneic bone marrow cells; these will be 
referred to as 'deprived' animals. The third group of animals was treated as above but was then given a thymus graft (Doenhoff, Davies, Leuchars, and Wallis, 1970): these will be referred to as 'reconstituted' animals. The thymus grafts were removed 30 days after insertion.

The Gardner lymphoma sarcoma was used as the transplanted tumour. This tumour, originally induced in $\mathrm{C} 3 \mathrm{H}$ mice, has been maintained here by serial passage in CBA mice since 1968 (Dougherty, Gardner, and Williams, 1944). Under inhalational anaesthesia with methoxyfluane laparotomy was performed and a tumour cell suspension made up to a known cell concentration was injected using a 25 gauge needle in a total volume of $0.05 \mathrm{ml}$ into the submucosa. With practice it was possible to do this quickly without penetrating to the lumen of the bowel and at the same time minimize leakage. Tumour was injected either into the region of the glandular stomach or into the small bowel $5-6 \mathrm{~cm}$ from the ileo-caecal region. After closing the laparotomy wound the animals were observed and subsequent progress was noted. At the end of four weeks, if the animals had not died, they were killed and a search made for tumour in the stomach or small bowel and observed tumours were confirmed histologically. The tumour was maintained by serial passage in the ascitic form in CBA mice and after counting was diluted with TC199 to the required cell concentration. In all cases the viability of the cells was greater than $95 \%$ as assessed by trypan blue exclusion.

\section{Results}

The resultsshow (see table) that tumours developed in $65 \%$ of normal mice injected with $4 \times 10^{4}$ cells into the stomach whereas when injected into the small bowel $34 \%$ developed tumours, a statistically significant difference. In the 'deprived' mice injected with either $4 \times 10^{4}$ cells or $2 \times 10^{3}$ cells there was no significant difference in the numbers of tumours developing in the two different sites. With the lower dose of cells there appeared to be an increase in the numbers of tumours of the small bowel. With the reconstituted animals given $4 \times 10^{4}$ cells the results

\begin{tabular}{llcll}
\hline Mice & $\begin{array}{l}\text { No. of Tumour } \\
\text { Cells }\end{array}$ & $\begin{array}{l}\text { Percentage } \\
\text { Stomach } \\
\text { Tumours }\end{array}$ & $\begin{array}{l}\text { Percentage } \\
\text { Small Bowel } \\
\text { Tumours }\end{array}$ & P \\
\hline Normal & $4 \times 10^{4}$ & 65 & 34 & 0.05 \\
Deprived & $4 \times 10^{4}$ & 100 & 93 & NS \\
Reconstituted & $2 \times 10^{3}$ & 50 & 86 & NS \\
\hline
\end{tabular}

Table Incidence of tumours of stomach or small bowel after transplantation of the Gardner lymphoma showed that there was a significant increase in the number of tumours developing in the stomach. It is of interest that there was a higher incidence of stomach tumours in the reconstituted animals as compared with the controls.

\section{Discussion}

In the experimental model described here the incidence of tumours in the small bowel parallels the clinical situation. In the deprived animals in which the number of $T$ (thymus-deprived) cells, those cells responsible for graft and tumour rejection (Raff, 1973), has been drastically reduced and the incidence of tumours in the stomach and small bowel is similar. It could be argued however that the radiation given might have altered locally the capacity of the gut to accept tumour challenge. It is for this reason that the reconstituted group of animals forms an important control. These animals have been given the same dosage of radiation as the deprived animals, yet the presence of a functioning thymus graft restoring the $T$ cell pool results in a significant decrease in the tumour take in the small bowel.

From the clinical point of view it is important that these results are confirmed in the human situation. The study would involve quantitation of the immune response in the peripheral blood and some estimate of the local immune response in the small bowel. Experimental work is now under way in this area. Further, in conditions of the small bowel such as Crohn's disease or coeliac disease a prospective study of the immunological status of the small bowel may indicate which patients will subsequently develop neoplastic change.

This work was done while the author was the holder of an MRC clinical research fellowship at the Chester Beatty Research Institute, London. The work could not have been completed without the encouragement and advice of Dr E. Leuchars and Dr A. J. S. Davies.

\section{References}

Barry, R. E., and Read, A. E. (1973). Coeliac disease and malignancy Quart. J. Med., 665-675.

Darke, S. G., Parks, A. G., Grogono, J. L., and Pollock, D. J. (1973). Adenocarcinoma and Crohn's disease. Brit. J. Surg., 60, 169-175.

Doenhoff, M. J., Davies, A. J. S., Leuchars, E., and Wallis, V. (1970). The thymus and circulating lymphocytes of mice. Proc. roy. Soc. Lond., B, 176, 69-85.

Ferguson, A., and Parrott, D. M. V. (1972). The effect of antigen deprivation on thymus dependent and thymus independent lymphocytes in the small intestine of the mouse. Clin. exp. Immunol., 12, 477-486.

Gardner, W. U., Dougherty, T. F., and Williams, W. L. (1944). Lymphoid tumors in mice receiving steroid hormones. Cancer Res., 4, 73-87.

Gatti, R. A., and Good, R. A. (1971). Occurrence of malignancy in immunodeficiency diseases. Cancer (Philad.), 28, 89-98.

Lowenfels, A. B. (1973). Why are small bowel tumours rare? Lancet, 1, 24-26. 
Moore, A. R., and Hall, J. G. (1972). Evidence for a primary association between immunoblasts and small gut. Nature (Lond.), 239, 161-162.

Penn, I., and Starzl, T. E. (1972). Malignant tumours arising de novo in immunosuppressed organ transplant recipients. Transplantation, 14, 407-417.
Samson, R. R., McClelland, D. B. L., and Shearman, D. J. C. (1973). Studies on the quantitation of immunoglobulin in human intestinal secretions. Gut, 14, 616-626.

Raff, M. C. (1973). T and B lymphocytes and immune responses. Nature (Lond.), 242, 19-23. 